\begin{tabular}{ll}
\hline 臨 & 床 \\
\hline
\end{tabular}

\title{
突発性難聴における歪成分耳音響放射出力と聴力予後
}

\author{
森貴稔・平木 信明・橋田 光一 \\ 永谷 群司・上田 成久・鈴木 秀明
}

\section{Distortion Product Otoacoustic Emissions and Hearing Outcomes in Idiopathic Sudden Sensorineural Hearing Loss}

\author{
Takanori Mori, Nobuaki Hiraki, Koichi Hashida, \\ Gunji Nagatani, Narihisa Ueda and Hideaki Suzuki \\ (University of Occupational and Environmental Health)
}

\begin{abstract}
We investigated the clinical usefulness of distortion product otoacoustic emissions (DPOAEs) for the prediction of hearing outcomes in idiopathic sudden sensorineural hearing loss (ISSNHL).

Thirty-two patients with ISSNHL (time from the onset to the start of treatment $\leqq 14$ days) were enrolled in the study. They received steroid administration $(400 \mathrm{mg} /$ day of hydrocortisone sodium succinate followed by tapered doses) combined with hyperbaric oxygen therapy. DPOAEs (f2/f1 $=1.2, \mathrm{~L} 1=80 \mathrm{~dB}-$ SPL, L2 $=70 \mathrm{dBSPL}$, geometric mean (GM) of $\mathrm{f} 1$ and $\mathrm{f} 2=531-5,500 \mathrm{~Hz}$, every one-third octave) were measured before and after treatment. The degree of hearing recovery was classified into four categories (complete recovery, good recovery, satisfactory recovery, no change) according to the criteria of the Ad Hoc Committee of the Japanese Ministry of Health, Labour and Welfare.

The DPOAE output in the high-frequency range (GM of f1 and $\mathrm{f} 2 \geqq 2,781 \mathrm{~Hz}$ ) before treatment was higher in the complete recovery group than in the other three groups. The DPOAE output at $2,781 \mathrm{~Hz}$ and $4,375 \mathrm{~Hz}$ was significantly higher in the complete recovery than in the satisfactory recovery and no change groups (Student's t-test, $\mathrm{p}<0.05$ ). However, the improvement of the DPOAE output after treatment did not statistically differ at any frequency among the four groups.

These results indicate that the DPOAE output in the high-frequency range before treatment can be a prognostic indicator of hearing outcomes in patients with ISSNHL.
\end{abstract}

Key words : idiopathic sudden sensorineural hearing loss, distortion product otoacoustic emission, hearing outcome, steroid, hyperbaric oxygen therapy

はじめに

突発性難聴は急性に発症する原因不明の感音難聴であ

る. その病態として内耳の局所循環障害, ウイルス感染, 内耳空破裂, 自己免疫などの可能性が示唆されている11. 発生する内耳障害の中で, 外有毛細胞の障害の程度を知
ることは, 聴力予後を考えるらえでの重要な手がかりの 一つであろうと推察される. Kemp ${ }^{2)}$ によって初めて報告 された耳音響放射は外有毛細胞の機能に深くかかわるも のであり, 現在のところ誘発耳音響放射 (EOAE), 自発 耳音響放射 (SOAE), 歪成分耳音響放射 (DPOAE), 周 
期性耳音響放射（SEOAE）に分類されている。このうち EOAE の研究は耳音響放射の中でも比較的歴史が古く, 臨床的にも数々の報告がある ${ }^{3)}$ 5) が, 主として $1 \sim 2 \mathrm{kHz}$ の周波数成分からなり，低〜中音域の聴覚の評価に有用 とされている．これに対し，DPOAE は低音域の刺激音 による反応は検出されにくいが，中〜高音域にわたる広 い周波数で測定可能であり周波数特異性も高いといわれ ている6) 8). このため低音障害型感音難聴を除いた突発 性難德における DPOAE の検討は，予後予測に有用であ ろうと考えられる。一般的に DPOAE は周波数特異性に 優れ，かつ非侵襲的であり，短時間に測定が可能といっ た長所がある一方で，中等度以上の感音難聴では検出さ れにくいと考えられているため, 中等度以上の難聴が多 い突発性難聴への応用はあまり普及していない899). 今回 われわれは突発性難聴症例において, 初診時と治療後に DPOAEを測定し, 聴力予後との関係について検討を行っ た.

\section{対象と方法}

当科を受診した一側性の突発性難聴患者のうち，糖尿 病，肝炎，消化性潰瘍などの基礎疾患を有する場合や治 療拒否例および低音障害型急性感音性難聴 (平成 12 年度 厚生省急性高度難聴調查研究班の診断基準) 10) の症例を 除いた，発症から治療開始までの期間が 14 日以内の 32 症例 32 耳を対象として検討を行った. 初診時にまず十分 に鼓膜を観察し，外耳道や鼓膜所見に異常がある者や， 純音聴力検查データ上明らかに伝音難聴を呈している者 は除外した。本シリーズ初診時聴力レベルの内訳は，突 発性難聴重症度分類(平成 10 年度厚生省特定疾患急性高 度難聴調查研究班の重症度分類） 11）(表 1）に従らと, Grade 1 から Grade 4 までおの㧈の 0, 9, 12, 11 例であっ た. 治療法としては，全例に対し入院のうえ，ステロイ ド投与（表 2)，高気圧酸素療法（HBO）を行った. HBO は $100 \% \mathrm{O}_{2}$ 吸入下に 2.5 気圧, 60 分を 1 日 1 回 $\times$ 週 5 回

表 1 突発性難聴重症度分類に基づく分類（平成 10 年度厚生省 特定疾患急性高度難聴調査研究班研究業績報告書より 11 )

Grade $1: 40 \mathrm{~dB}$ 未満

Grade 2: $40 \mathrm{~dB}$ 以上 $60 \mathrm{~dB}$ 未満

Grade $3: 60 \mathrm{~dB}$ 以上 $90 \mathrm{~dB}$ 未満

Grade $4: 90 \mathrm{~dB}$ 以上

聴力は $0.25,0.5,1,2,4 \mathrm{kHz}$ の 5 周波数の閾值の平均とする $\times 2$ 週間（計 10 回）施行した. ステロイド投与はコハク 酸ヒドロコーチゾンを $400 \mathrm{mg} / \mathrm{day} よ り$ 開始し9日かけて 漸減点滴投与し，その後プレドニゾロンを内服に変え 5 日かけて漸減投与した。治療開始後 1力月の時点を聴力 固定時の聴力とし，突発性難聴聴力回復の判定基準（昭 和59年度厚生省特定疾患突発性難聴調查研究班の判定基 準) 12)（表 3）に基づいた結果の内訳は治癒群，著明回復 群，回復群，不変群おのおの $8,4 ， 8 ， 12$ 例であった. また，聴力の回復程度を数值化するために聴力改善率を 用い，次式にて各症例算出した。

聴力改善率 $=\frac{(\text { 初診時聴力レベルー固定時聴力レベル) }}{(\text { 初診時聴カレベルー健側聴カレベル })} \times 100 \%$

DPOAE の測定は両耳に対して初診時と聴力固定時 に防音室にて行った。使用機器は永島医科機械製 GSI-60 である. 測定条件は 2 つの入力音 $\mathrm{f} 1, \mathrm{f} 2 （ \mathrm{f} 1<\mathrm{f} 2 ）$ の周波

表 2 産業医科大学耳鼻咽喉科にて行っている突発性難聴に対 するステロイド投与のプロトコール

\begin{aligned} \hline \hline Day & & & \\ \hline 1 & コハク酸ヒドロコルチゾン & $400 \mathrm{mg} &$ 点滴静注 \\ 2 & コハク酸ヒドロコルチゾン & $400 \mathrm{mg} &$ 点滴静注 \\ 3 & コハク酸ヒドロコルチゾン & $400 \mathrm{mg} &$ 点滴静注 \\ 4 & コハク酸ヒドロコルチゾン & $200 \mathrm{mg} &$ 点滴静注 \\ 5 & コハク酸ヒドロコルチゾン & $200 \mathrm{mg} &$ 点滴静注 \\ 6 & コハク酸ヒドロコルチゾン & $200 \mathrm{mg} &$ 点滴静注 \\ 7 & コハク酸ヒドロコルチゾン & $100 \mathrm{mg} &$ 点滴静注 \\ 8 & コハク酸ヒドロコルチゾン & $100 \mathrm{mg} &$ 点滴静注 \\ 9 & コハク酸ヒドロコルチゾン & $100 \mathrm{mg} &$ 点滴静注 \\ 10 & プレドニゾロン & $10 \mathrm{mg} &$ 内服（分 1) \\ 11 & プレドニゾロン & $10 \mathrm{mg} &$ 内服（分 1) \\ 12 & プレドニゾロン & $10 \mathrm{mg} &$ 内服（分 1) \\ 13 & プレドニゾロン & $5 \mathrm{mg} &$ 内服 \\ 14 & プレドニゾロン & $5 \mathrm{mg} &$ 内服 \end{aligned}

表 3 突発性難聴聴力回復の判定基準に基づく分類（昭和 59 年 度厚生省特定疾患突発性難聴調查研究班研究業績報告書 より ${ }^{12)}$ )

治癒：1） $0.25,0.5,1,2,4 \mathrm{kHz}$ の聴カレベルが $20 \mathrm{~dB}$ 以内に 戻ったもの

2）健側聴力が安定と考えられれば，患側がそれと同程 度まで改善したとき

著明回復: 上記 5 周波数の算術平均値が $30 \mathrm{~dB}$ 以上改善したとき 回復：上記 5 周波数の算術平均值が $10 \mathrm{~dB}$ 以上 $30 \mathrm{~dB}$ 未満改善 したとき

不変 : 同じくの值が $10 \mathrm{~dB}$ 末満の変化 
数比を 1.2, f1 の音圧 L1 を $80 \mathrm{dBSPL}, \mathrm{f} 2$ の音圧 L2 を $70 \mathrm{dBSPL}$ とし, $\sqrt{\mathrm{f} 1 \times \mathrm{f} 2}=531 \sim 5500 \mathrm{~Hz}$ の範囲で, 3 分 の 1 オクターブごと, 計 11 周波数において DPOAE およ びノイズフロアーの計測を行った。難聴が高度になると DPOAE は検出困難になる傾向はあったが, 今回の検討で は DPOAE がノイズフロアーより小さかった者のデータ は含めていない.さらに DPOAE 出力と DPOAE 出力改 善度を次の 2 式にて算出した。

DPOAE出力 $(\mathrm{dB})=$ DPOAE output $(\mathrm{dB}$ SPL $)-$ Noise Floor (dB SPL)

DPOAE 出力改善度 $(\mathrm{dB})=$ 聴力固定時 DPOAE 出力 $(\mathrm{dB})$ 一初診時 DPOAE 出力 $(\mathrm{dB})$

対側良聴耳をコントロールとし，データは平均土標準誤 差として表記した。 また, 対側良聴耳のデータが明らか
にコントロール群と異なっていた場合や，データの再現 性に乏しい場合は，複数回測定を行い評価した。 それぞ れの群の平均値の差は Student's t-test にて解析し, $\mathrm{p}<$ 0.05 をもって有意差ありとした.

\section{結 果}

初診時 5 分法聴力レベルと聴力改善度との回帰直線を 図 1 亿示す．相関係数 $\mathrm{R}=0.337$ であり，負の相関を示 し，難聴が高度になれば改善率も低くなるが，回帰分析 の結果, 統計学的に有意な相関はなかった $(\mathrm{p}=0.0591)$. 次に初診時の難聴の程度と高周波数域の DPOAE 出力の 関係を検討した．初診時 5 分法聴力レベルと入力音周波 数 $4375 \mathrm{~Hz}$ における初診時 DPOAE 出力との回帰直線を 図 2 に示す. 相関係数 $\mathrm{R}=0.33$ であり, 負の相関を示 し, 難聴が高度になれば出力は低下していたが, 回帰分

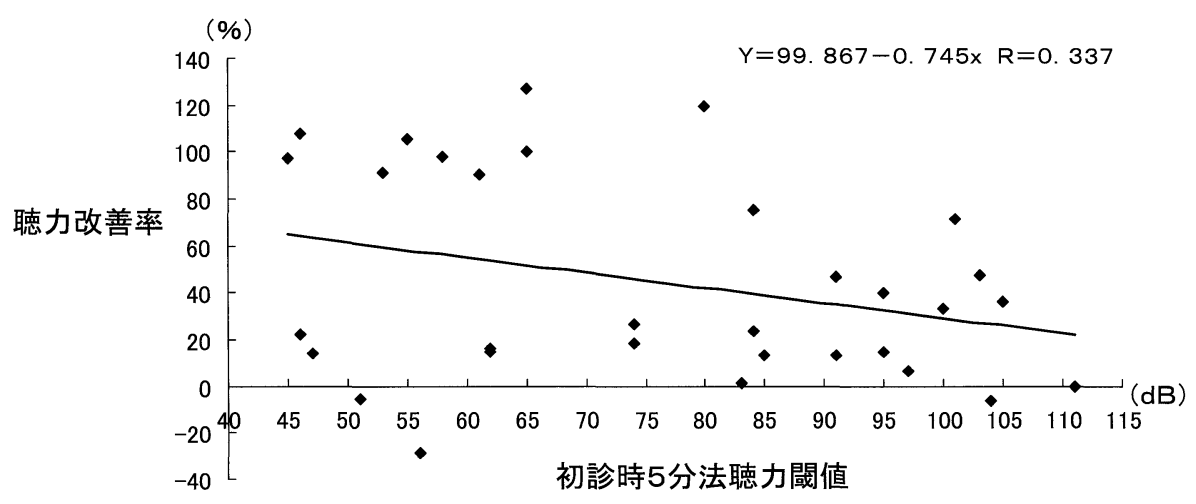

図 1 初診時 5 分法聴力閾值と聴力改善率

初診時 5 分法聴力閾值が大きくなると, 聴力改善率は低下しているが, 統計学的に有意な相関はない.

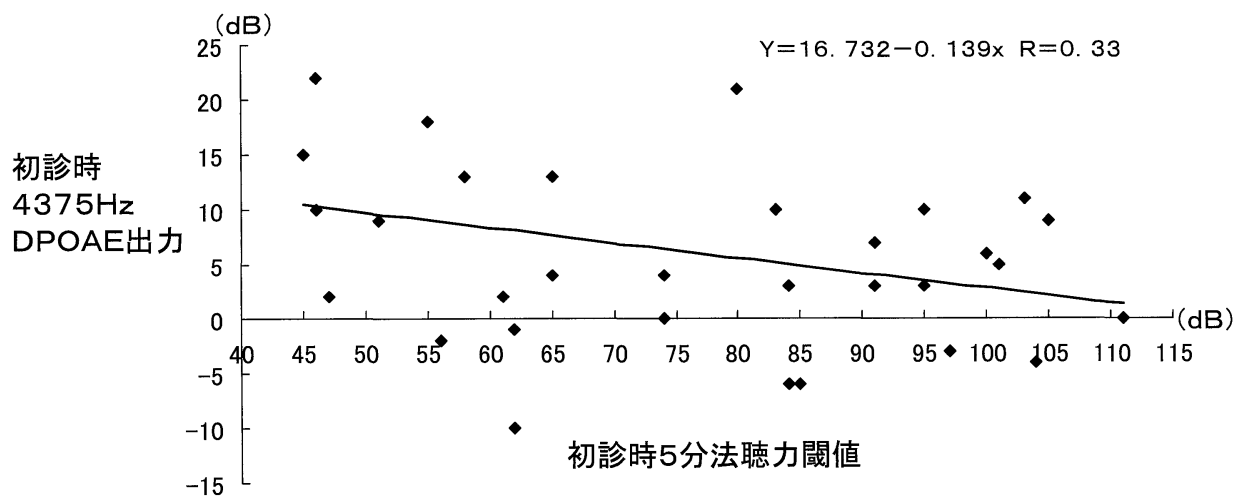

図 2 初診時 5 分法聴力閾値と入力音周波数 $4375 \mathrm{~Hz}$ の初診時 DPOAE 出力

初診時 5 分法聴力閾值が大きくなると，入力音周波数 $4375 \mathrm{~Hz}$ の初診時 DPOAE 出力は小さくなるが，統計学的に有意な相関は ない. 


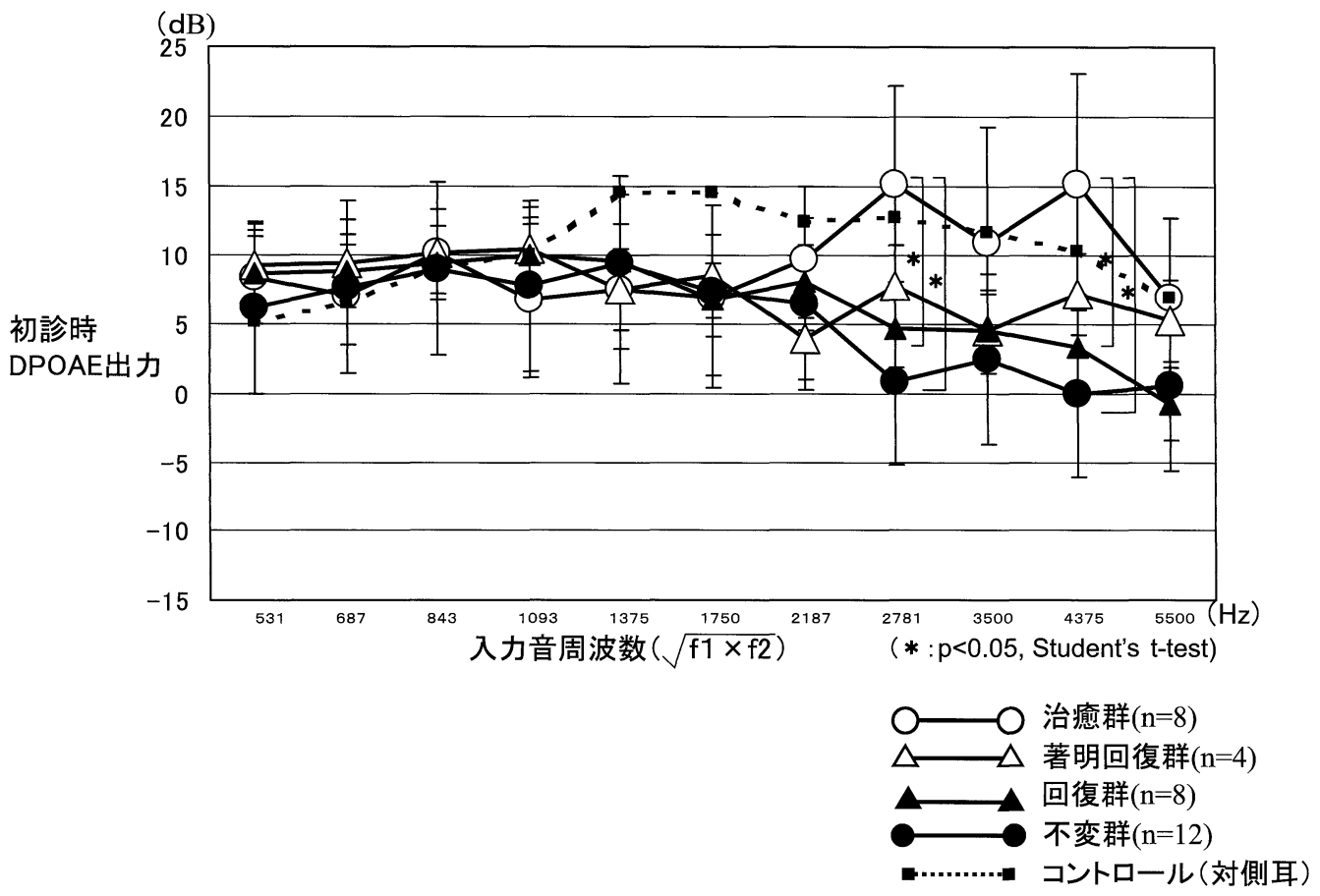

図 3 聴力回復別に分けた各群の初診時 DPOAE 出力

入力音が $2781 \mathrm{~Hz}$ 以下の周波数域では 4 群間での初診時 DPOAE 出力にほとんど差は認められず, $2781 \mathrm{~Hz}$ 以上の高周波数域に おいて治癒群が他の 3 群に比べて大きい. 入力音周波数が $2781 \mathrm{~Hz}$ と $4375 \mathrm{~Hz}$ の 2 周波数において治癒群と回復群，治癒群と不 変群との間に統計学的有意差がみられる（ $* ; \mathrm{p}<0.05$, Student's t-test）. また，この 2 周波数では治癒群はコントロールより も出力が大きい.

析の結果, 統計学的に有意な相関はなかった $(\mathrm{p}=$ 0. 0653). 聴力回復別に分けた各群の初診時 DPOAE 出力 を図 3 に示す. 入力音周波数が $531 \sim 2187 \mathrm{~Hz}$ の 7 周波 数においては各群間にほとんど差はなく, 統計学的にい ずれの 2 群間にも有意差は認められなかった. $2781 \mathrm{~Hz}$ 以上の 4 周波数においては, 治癒群が他の 3 群に比べ明 らかに出力は大きく, 統計学的に比較検討すると, 入力 音周波数 $2781 \mathrm{~Hz}, 4375 \mathrm{~Hz}$ において治癒群と回復群, 治癒群と不変群との間に有意差があった $(\mathrm{p}<0.05$, Student's t-test). またこの 2 周波数において, 治癒群はコ ントロールよりも出力が大きかった. 次に聴力回復別に 分けた各群の DPOAE 出力改善度を図 4 に示す. 531 〜 $5500 \mathrm{~Hz}$ の 11 周波数すべてにおいて治癒群, 著明回復群, 回復群，不変群のいずれの 2 群間でも統計学的に差がな かった。

\section{考察}

DPOAE は外〜中耳が正常な場合, 出現率は高く, かつ ヒトの聴覚の大部分を占める広い周波数域において安定
に再現性も高く検出できる ${ }^{8) 13)}$. また，周波数特異性が 非常に高く, DPOAE レベルは蝸牛内の特定の狭い領域 の外有毛細胞機能を反映するといわれている7710). 入 力音として $\mathrm{f} 1$ と $\mathrm{f} 2$ という 2 音を与えた場合, $2 \mathrm{f} 1$ - $\mathrm{f} 2$ で 検出される DPOAE 出力が, どの周波数領域の外有毛 細胞機能を反映するかについては, $\mathrm{f} 1$ と $\mathrm{f} 2$ の相乗平 均（ $\sqrt{\mathrm{f} 1 \times \mathrm{f} 2})$ をとる場合と，単に $\mathrm{f} 2$ をとる場合とがあ る613)14). 今回の検討では, 使用した機械のソフトで前者 の相乗平均が選択されている.

今回の検討症例からは低音障害型感音難聴は除外され ており, すべての症例で中〜高音域の障害を伴っていた ため, この周波数域に対応する蝸牛機能の残存度の差が 聴力予後に関与することが考元られる. 突発性難聴の病 態については現在までさまざまな方向から解析が行われ てきた ${ }^{15) 16)}$ ，その一つとして古くから内耳虚血に関する 研究がなされており, その病態解明を目指して種々の動 物実験が行われてきた. Hakuba ら ${ }^{17)}$ によると, 一過性 （15 分間）の内耳虚血負荷実験で虚血にとくに脆弱なの は内有毛細胞や血管条であり, そのらち血管条障害は可 


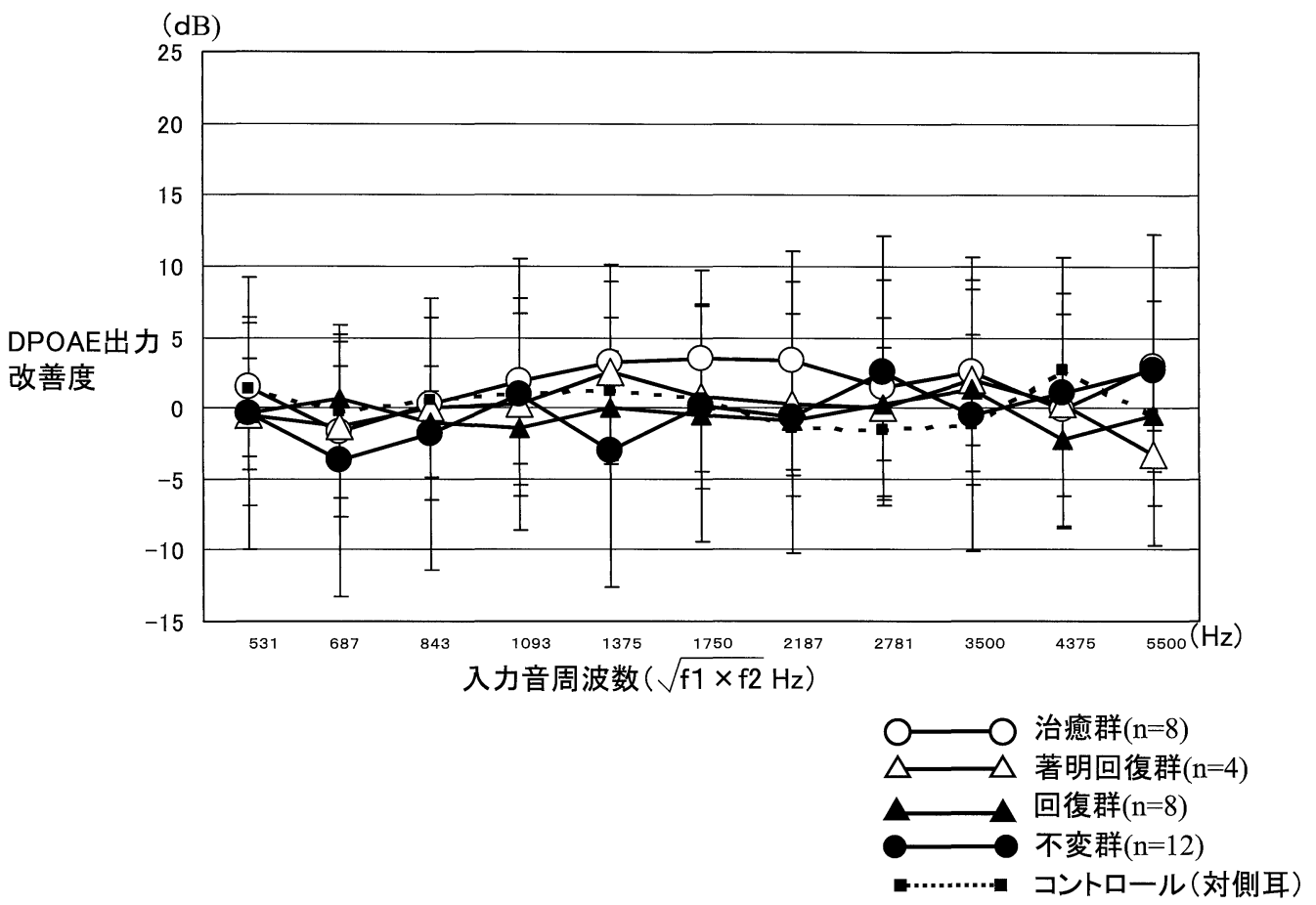

図 4 聴力回復別に分けた各群の初診時と聴力固定時の DPOAE 出力改善度 全周波数にて，4群におけるいずれの 2 群間においても統計学的に有意差はない.

逆性であるのに対し内有毛細胞障害は不可逆性のことが 多かったとされている，そして外有毛細胞は内有毛細胞 に比べると比較的軽度な障害しか受けなかったことも報 告している.さらに蝸牛基底回転は頂回転に比べて約 2.5 倍の酸素を消費することから高周波数域は虚血障害に対 する受傷性が高いと考えられる ${ }^{18)}$ ，仮にこの内耳虚血が 突発性難聴の病態にあてはまるとすると, 高周波数域の 障害は発症初期の段階から生じやすく, かつ比較的軽度 な障害しか受けないと考光られる外有毛細胞が初診時に より強い障害を受けていた場合, 回復しにくかったので はないかと考えられる.今回の結果を初診時聴力レベル ごとに分けて検討していないが，突発性難聴で入院した 症例全体でみると $2781 \mathrm{~Hz}$ 以上といった高周波数域の外 有毛細胞機能が初診時に残存しているほど突発性難聴の 聴力予後は良いという結果を得た。川尻ら ${ }^{19)}$ は純音聴力 閾值が $60 \mathrm{~dB}$ 以上にもかかわらず，当該周波数領域にお いて DPOAE が検出された場合には聴力の予後は比較的 良好な傾向にあったと報告しており，さらに DPOAE が 良好に検出される症例の障害部位については, 血管条障 害が生じているが有毛細胞の障害までには至っていない
可逆的な状態が DPOAE に反映されるのではないかと推 測している。 また Schweinfurth ら ${ }^{15)}$ は，ステロイドにて 治療した急性感音難聴の患者の検討において，初診時に 正常な DPOAE 出力があった症例では純音聴力検查の 3 周波数 $(0.5,1.0,2.0 \mathrm{kHz})$ の平均聴力が $33 \mathrm{~dB}$ 改善 し，DPOAE が検出されなかった場合にはほとんどが改 善しなかったと報告している，以上のことより，初診時 の DPOAE 出力を検討することは突発性難聴の聴力予後 を語るらえで非常に重要であると考えられる。

次に今回の検討の結果では, 治療による DPOAE 出力 改善度と聴力改善度に関連性はみられなかった。このこ とは今回行った治療（ステロイド+ HBO）が外有毛細胞 機能に対してはあまり有効ではなかったことを示唆する ものではないかと考える．われわれが過去に報告してき た動物実験でも，内耳障害に対するステロイド投与は外 有毛細胞ではなく内有毛細胞やその周囲組織に作用する ことを示す所見を得ている ${ }^{20211}$. 突発性難聴における聴 力予後の予測は, 治療を開始するらえでの重要なポイン トであり, 精度の高い予後予測を可能にするため, 今後 さらに症例を重称て初診時聴力レベルごとに分けた初診 
時 DPOAE 出力を検討していく予定である.

\section{まとめ}

1. 突発性難聴の予後予測のために, 初診時 DPOAE 出 力と聴力予後, および初診時一聴力固定時 DPOAE 出力 改善度と聴力予後との関係を検討した.

2. 高周波数域の初診時DPOAE出力が大きいほど聴力 予後は良好であった。

3. 初診時一聴力固定時DPOAE出力変動は聴力予後に 関与しなかった。

4. 初診時DPOAE出力測定は突発性難聴の予後予測検 查として有用であり, 発症初期の突発性難聴において施 行してみる価值があると考えられた。

\section{参考文献}

1) Suzuki H, Furukawa M, Kobayashi T, et al. : Defibrinogetion therapy for idiopathic sudden sensorineural hearing loss in comparison with high-dose steroid therapy. Acta Otolaryngol $123: 46 \sim 50,2003$.

2) Kemp DT : Stimulated acoustic emissions from within the human auditory system. J Acoust Soc Am $64: 1386 \sim 1391$, 1978.

3）井上庸夫，田中康夫，石田和男，他： $\mathrm{EOAE}$ 潜時成分加ら みた低音障害型急性感音難聴および突発性難聴の予後. Audiol Jpn $41: 135 \sim 141,1998$.

4）邸 向丹, 服部 玩, 丹羽英人, 他: 誘発耳音響放射によ る突発性難聴の経過観察. Audiol Jpn 38:222〜 228, 1995.

5) Lutman ME, Manson SM, Sheppard S, et al. : Differential diagnostic potential of otoacoustic emissions: a case study. Audiology $28: 205 \sim 210,1989$.

6) Moulin A, Bera JC and Collet L : Distortion product otoacoustic emissions and sensorineural hearing loss. Audiology 33 : $305 \sim 326,1994$.

7）坂下哲史, 久保武志, 楠木 誠, 他：突発性難聴における 歪成分耳音響放射. Audiol Jpn $40: 100 \sim 108,1997$.

8）大沢宏秀, 藤原敏浩 : 突発性難聴の予後判定に有用であっ た誘発耳音響放射. Audiol Jpn 38 : $141 \sim 144,1995$.

9) Hoth S : On a possible prognostic value of otoacoustic emissions: a study on patients with sudden hearing loss. Eur Arch
Otorhinolaryngol $262: 217 \sim 224,2005$.

10）村井和夫, 岡本牧人：急性低音障害型感音難聴一初回発作 例の検討一厚生省特定疾患急性高度難聴調査研究班平成 12 年度研究業績報告書 : $37 \sim 39$ 頁, 2001 .

11）星野知之，福田 諭，宇佐美真一：突発性難聴，特発性両 側性感音難聴の重症度分類案の作成. 厚生省特定疾患急性 高度難聴調查研究班平成 10 年度研究業績報告書 : 37 頁, 1998.

12）野村恭也：総括研究報告. 厚生省特定疾患急性高度難聴調 查研究班昭和 59 年度研究業績報告書 : $1 \sim 3$ 頁, 1985 .

13）大山健二, 和田 仁, 高坂知節: 歪成分耳音響放射 (DPOAE) による蝸牛機能の評価. Audiol Jpn $35: 46 \sim 55,1992$.

14) Smurzynski J and Kim DO : Distortion-product and clickevoked otoacoustic emissions of normally-hearing adults. Hear Res $58: 227 \sim 240,1992$.

15) Schweinfurth JM, Cacace AT and Parnes SM : Clinical applications of otoacoustic emissions in sudden hearing loss. Laryngoscope $107: 1457 \sim 1463,1997$.

16) Nakamura $M$, Yamasoba $T$ and Kaga $K$ : Changes in otoacoustic emissions in patients with idiopathic sudden deafness. Audiology $36: 121 \sim 135,1997$.

17) Hakuba N, Koga K, Shudou M, et al. : Hearing loss and glutamate efflux in the perilymph following transient hindbrain ischemia in gerbils. J Comp Neurol $418: 217 \sim 226,2000$.

18) Mizukoshi $O$ and Daly JF : Oxygen consumption in normal and kanamycin damaged cochleae. Acta Otolaryngol $64: 45 \sim 54$, 1967.

19）川尻逸平，神田幸彦，小林俊光，他：突発性難聴における 歪成分耳音響放射の検討. Audiol Jpn $42 ： 88 ＼mathrm{~ 93 ， ~} 1999$.

20) Mori T, Fujimura K, Suzuki H, et al. : Effects of glucocorticoid receptor antagonist on CAPs threshold shift due to short-term sound exposure in guinea pigs. Auris Nasus Larynx 31:395 399, 2004.

21）森 貴稔，藤村和伸，鈴木秀明，他：内耳性聴覚障害に対 するステロイド効果発現部位の検討. Audiol Jpn $50: 150$ 〜 156, 2007.

原稿受付：平成 20 年 3 月 17 日 原稿採択：平成20年 6 月 26 日 別刷請求先 : 森 貴稔 厂 807-8555 北九州市八幡西区医生ヶ丘1-1 産業医科大学医学部耳鼻咽喉科学講座 